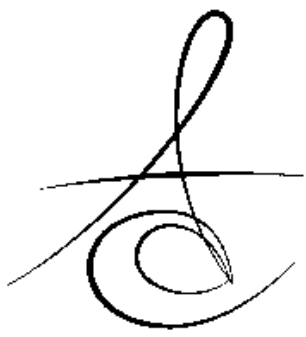

\title{
THE ORDERING OF SMOKERS' TOOTHPASTE CHOICE CRITERIA WITH FUZZY MODEL
}

\author{
BULANIK MODEL İLE SİGARA İÇENLERİN DİŞ MACUNU SEÇİM \\ KRİTERLERİNİN SIRALANMASI
}

Ergün Alperay TARIM*

Prof. Dr. Vildan MEVSİM ${ }^{* * *}$

\author{
Makale Kodu/Article code: 3945 \\ Makale Gönderilme tarihi; 31.12.2018 \\ Kabul Tarihi: 17.05.2019
}

\section{ABSTRACT}

Aim: There are some measures that smokers can cease or prevent damage caused by smoking. They may also choose some product features that may be more helpful to them like toothpaste selection etc. The preferences of smokers vary because of the variety of toothpaste in the market and a high number of products. The aim of this study is to determine the importance of toothpaste selection criteria in order to determine the decision and toothpaste selection.

Material and method: Fuzzy DEMATEL model is used effectively in decision making problems. This model, which can rank the decision criteria in order of importance even for a single individual, is a more effective and important model in ordering the decision criteria of a large number of individuals. In this study, fuzzy DEMATEL model was used to determine the importance of toothpaste selection criteria. In this study, 7 toothpaste selection criteria were determined by data obtained by taking user and expert opinions. After the determination of criteria, the information form was applied to the model to show the criterion importance preferences of smokers.

Results: According to the preferences of smokers, the selection criteria of toothpaste were placed in the order with the fuzzy DEMATEL model. The most important criteria is toothpaste package appearance, while the least of the 7 criteria is determined as the criteria that Sensation of Person.

Conclusion: As a result, the toothpaste properties that the smokers would prefer, ie the toothpaste selection criteria are listed in importance. In other words, it is given the ranking of preference criteria for smokers when choosing toothpaste.

Keywords: Toothpaste, fuzzy logic, smoking, decision making

\section{öz}

Amaç: Sigara içmenin verdiği zararları yok edebilmek ya da önleyebilmek için sigara kullanıcılarının alabilecekleri, diş macunu seçimi vb, bazı önlemler vardır. Ayrıca, bu konuda kendilerine daha yararlı olabilecek bazı ürün özelliklerini tercih edebilirler. Piyasadaki diş macunu çeşitliliği ve ürünlerin belirleyici özelliklerinin fazla olması nedeni ile sigara kullanıcılarının tercihleri değişiklik göstermektedir. Sigara kullanıcılarının diş macunu seçiminde verdikleri kararları ve önem verdikleri özellikleri belirlemek adına yapılan bu çalışmada, diş macunu seçim kriterlerinin önem sırasına konulması hedeflenmiştir.

Gereç ve yöntem: Bulanık DEMATEL modeli karar verme problemlerinde etkin kullanılan bir modeldir. Tek birey için dahi karar kriterleri önem sırasına göre sıralayabilen bu model, çok sayıda bireylerin karar kriterlerinin sıralamasıda daha etkili ve önemli bir modeldir. Bu çalışmada diş macunu seçim kriterlerinin önem sırasının belirlenmesi adına, bulanık DEMATEL modeli kullanılmıştır. Kullanıcı ve uzman görüşleri alınarak elde edilen veriler ile 7 adet diş macunu seçim kriteri belirlenmiştir. Kriterlerin belirlenmesi sonrasında bilgi formu sigara içen bireylerin kriter önem tercihlerini göstermek adına modele uygun bir şekilde uygulanmıştır. Bulgular Sigara içenlerin tercihlerine göre oluşturulan bulanık DEMATEL modeli ile diş macunu seçim kriterleri önem sırasına konmuştur. Kriterlerden en önemlisi diş macunu paket görünümü olurken, belirlenen 7 kriterden en az önemlisi bireyin ürünü kullanırken hissettikleri kriteri olarak bulunmuştur.

Sonuç: Sonuç olarak çalışmada, sigara içenlerin tercih edecekleri diş macunu özellikleri yani ürün tercih kriterleri önem sırasında sıralanmaktadır. Başka bir deyişle, sigara içenlerin diş macunu seçimi yaparken önem verdikleri tercih kriterlerinin sıralaması verilmiştir.

Anahtar kelimeler: Diş macunu, bulanık mantık, sigara içme, karar verme

\footnotetext{
* Izmir Institute of Technology, Department of Bioengineering, Urla, Izmir.

** Dokuz Eylül University, Department of Computer Science, Buca, Izmir.

*** Dokuz Eylül University, Department of Family Medicine, Inciralti, Izmir.

${ }^{*}$ This study was presented as an oral presentation at the 14th Annual Conference of the International Society for the Prevention of Tobacco Induced Diseases (TID). 4-6 October 2018, Izmir-Turkey.
} 
Atatürk Üniv. Diş Hek. Fak. Derg.

J Dent Fac Atatürk Uni

Cilt:29, Sayı:3, Yıl: 2019, Sayfa, 394-399
TARIM, KURUOĞLU KANDEMİR, MEVSIM

\section{INTRODUCTION}

Tobacco users are more vulnerable to dental and oral flora than non-smokers. ${ }^{1}$ These conditions may affect the decisions of tobacco users when buying toothpaste. Unlike non-smokers, tobacco user's toothpaste expectations may be different. The damages of smoking to dental and oral flora can be ordered like; cause tar residues or dark-brown spots on the teeth and red colored inflammatory formations in the palate, predisposition to gum disease, occasion to halitosis, lead to black hairy tongue lesions, be responsible to tissue disorders in the mouth, gingival recession, cancer etc. ${ }^{2,3}$

The purchasing behavior of consumers is affected by the status of economic, social, cultural, product feature, geographic region, demographic etc. Beyond that the market conditions of the purposed product also affect this behavior. These situations valid for purchasing tooth related products like toothpaste and gum. Vani et. al. analyzed consumer behaviors like awareness, preference etc. ${ }^{3,4}$

Tooth bleaching can be necessary if smokers consume beverages and that causes excessive coloration with tooth stains. With this purpose, Karadaş and Seven discussed the tooth bleaching practices of vital teeth in their study. ${ }^{5}$ On the other hand, tooth esthetics and whitening has a big role of self-confidence and psycho-social behavior of persons. ${ }^{6}$ These results show the tooth health and esthetics are important factors for human social life.

In the World Health Organization reports, various survey and methods were given for oral care and SPSS program was used. ${ }^{7}$ Given the importance of oral hygiene in preschoolers, their study was conducted to study selection and usage of toothpaste pattern among 3-5 years old children in Yazd, Iran. ${ }^{8}$

There are also researches about the ingredients of toothpaste and their effects on human health. Farooq et al. analyzed that the fluoride concentrations of the toothpaste brands and the effects of the children's oral health. ${ }^{9}$

Singh's study ${ }^{10}$ was aimed to identify the first source of information for toothpaste product, to know the media awareness of the consumer and to measure the effectiveness of different media. The research designed with 100 respondents, which consist of 50 males and 50 females. The sample of respondent was selected using the non-probability convenient sampling to know the views of respondent on a structured questionnaire and schedule was used wherever necessary. It was found that most of the respondents are well aware about the toothpaste product while the respondents were found to be most influenced by advertisement as well as atmosphere in the store in context of toothpaste.

We developed a decision model based on DEMATEL model and this model was created by the Battelle Memorial Institute through the Geneva Research Center and was used by Fontela and Gabus as a Decision-Making Trial and Evaluation Laboratory (DEMATEL) technique. ${ }^{11}$ DEMATEL is an expanded method to create a structural model for analyzing the relationship between complex related criteria.

In the light of this information, the aim of the study is try to find tobacco user's toothpaste decision criteria. Then we try to show these criteria of tobacco (generally cigarette) users in the selection of toothpastes and apply the DEMATEL model for rank criteria to order of importance and to calculate the effects of these criteria.

\section{MATERIAL AND METHOD}

The model applied in this study is the Fuzzy Decision-Making Trial and Evaluation Laboratory (Fuzzy DEMATEL). ${ }^{12}$ The model was used to determine the importance values of the criteria in the selection of toothpaste.

Fuzzy DEMATEL Model is the model consists of 7 steps,

Step 1: Determination of criteria and linguistic values: Criteria should be determined in terms of the problem, which is the selection of toothpaste in this study. The criteria should be truthful and understandable in the light of the information obtained from experts or literature.

Once the criteria have been determined, a fuzzy value should be given for each linguistic term. ${ }^{13}$ We try to order importance of the determined criteria. So, we have 5 different linguistic terms and their triangular fuzzy value representations (Table 1).

Step 2: Creating a Fuzzy Direct Relationship Matrix: A direct relationship matrix will be created for each criterion and this matrix will be a matrix consisting of elements with 0 on diagonal elements 
and non-symmetric. Table 2 is an example of the direct relationship matrix $\widetilde{Z}_{i j}$,

Table 1. Linguistic Terms of Fuzzy Value's. There are five different linguistic terms for description of fuzzy values.

\begin{tabular}{|l|l|}
\hline Linguistic Term & Fuzzy Value \\
\hline Very Low Importance (VLI) & $(0,0,0.25)$ \\
\hline Low importance (LI) & $(0,0.25,0,5)$ \\
\hline Medium Importance (MI) & $(0.25,0.5,0.75)$ \\
\hline High Importance (HI) & $(0.5,0.75,1)$ \\
\hline Very High Importance (VHI) & $(0.75,1,1)$ \\
\hline
\end{tabular}

Table 2. An example of the fuzzy direct relationship matrix

\begin{tabular}{|l|c|c|c|c|}
\hline $\mathbf{Z}_{\text {if }}$ & Criteria 1 & Criteria 2 & Criteria 3 & Criteria 4 \\
\hline Criteria 1 & 0 & VLI & LI & MI \\
\hline Criteria 2 & LI & 0 & VHI & HI \\
\hline Criteria 3 & HI & VHI & 0 & HI \\
\hline Criteria 4 & MI & MI & VLI & 0 \\
\hline
\end{tabular}

If $c$ is the number of criteria and $i,=[13 \ldots, c]$, there will be $\mathrm{H}$ different smokers' direct relationship matrix and the average direct relationship matrix was found Equation 1,

$$
\widetilde{o}_{i f}=1 / H \sum_{n=1}^{H} Z_{i j}^{n}
$$

Step 3: Create a Standardized Fuzzy Direct Relationship Matrix: The average direct relationship matrix could be written as triangular, $\left.\widetilde{\boldsymbol{o}}_{i \mathrm{if}}=\boldsymbol{l}_{\text {if }}, \boldsymbol{m}_{\mathrm{if},}, \boldsymbol{u}_{\mathrm{if}}\right)$. The standardized fuzzy direct relationship matrix was shown in Equation 2,

$$
\tilde{X}=\widetilde{x}_{i f}=\frac{\sigma_{y y}}{r}=\left(\frac{r_{y y}}{r_{i}}, \frac{m_{y y}}{r_{m}}, \frac{u_{y}}{r_{u}}\right) .
$$

where

$$
r_{l}=\max _{\mathbb{1} \leqslant i s n}\left(\sum_{j=1}^{n} t_{i j}\right) \quad r_{m}=\max _{1 \leq i \leq n}\left(\sum_{j=1}^{n} m_{i j}\right) \quad r_{u}=\max _{1 \leq i \leq n}\left(\sum_{j=1}^{n} u_{i j}\right) .
$$

Step 4: Defuzzyfication with CFCS method (Converting Fuzzy Data into Crisp Scores): We used CFCS for defuzzyfication of $\tilde{X}_{\text {matrix. }}{ }^{14,15}$ This method based on the normalization and finding the crisp scores of fuzzy values which are the elements of matrix $\tilde{X}_{\text {. }}$

Step 5: Creating a Fuzzy Total Relationship Matrix: The fuzzy total relationship matrix was shown in Equation 3,
$T=\lim _{H \rightarrow \infty}\left(\tilde{X}+\tilde{X}^{2}+\tilde{X}^{3}+\cdots+\tilde{X}^{H}\right)=\tilde{X}(I-\tilde{X})^{-1}$

where $I$ is the unit matrix and have same dimention with $\tilde{X}$.

Step 6: Calculating Fuzzy Affecting Factors and Affected Factors: The sum of th line of $T$ matrix is shown as $\tilde{D}_{i}$. This total shows the sum of the impacts that the th Criterion has affected other Criteria. Similarly, the sum of the th columns of the T matrix is shown as $\hat{\boldsymbol{R}}_{\bar{i}}$. This sum is expressed as the sum of the effects of the th Criterion influenced by the other Criteria. $\left(\tilde{D}_{i}-\hat{R}_{i}\right)$ shows that the degree of effect of the th criterion on the system and $\left(\tilde{D}_{i}+\tilde{R}_{i}\right)$ represent the degree to which the th criterion is affected by the system. ${ }^{16}$

Step 7: Determination of the fuzzy weights of the criteria: The weight of the criteria was found in Equation 5,

$$
\begin{gathered}
\boldsymbol{w}_{i}=\sqrt{\left(\tilde{D}_{i}+\tilde{R}_{i}\right)^{2}+\left(\tilde{D}_{i}-\tilde{R}_{i}\right)^{2}} \\
\text { then } \\
W_{i}=\frac{w_{i}}{\sum_{i=1}^{m} w_{i}} .
\end{gathered}
$$

The model applied to patients via survey. The survey was applied with open-ended questions and filling of the relationship matrix by patients. Questions have descriptive statistical information and empty $7 \times 7$ matrix which diagonal elements are 0.

At the beginning of the experiments, we obtained information about dental health and toothpaste was taken the personal information of the patients and the information related to dental health. Criteria were determined from the specialists and the patient survey. Each criteria described (Table 3) and serve to make patient's decision via relationship matrix. The criteria are advertisement and media effect, toothpaste content, toothpaste package appearance, influence of people, sensation of person, active ingrediens of toothpaste, price.

The direct relationship matrix data were obtained from patients who applied for quit smoking and were admitted to the Department of Family Medicine at Dokuz Eylül University. A total of 52 patients were analyzed with data. 
Table 3. Decription of criteria. We decided seven different criteria with the help of smokers and experts. Each criterias' description given to patients during the experiment and the patients ansver with respect to these criterias.

\begin{tabular}{|c|c|c|c|c|c|c|}
\hline $\begin{array}{l}\text { Advertising and } \\
\text { Media Effect }\end{array}$ & $\begin{array}{l}\text { Toothpaste } \\
\text { Content }\end{array}$ & $\begin{array}{l}\text { Toothpaste } \\
\text { Package } \\
\text { Appearance }\end{array}$ & $\begin{array}{l}\text { Influence of } \\
\text { (Other) } \\
\text { People }\end{array}$ & $\begin{array}{l}\text { Sensation of } \\
\text { Person }\end{array}$ & $\begin{array}{l}\text { The Active } \\
\text { Ingrediens of } \\
\text { Toothpaste }\end{array}$ & Price \\
\hline $\begin{array}{l}\text { Effect of producer } \\
\text { firm on market share, } \\
\text { The reliability of the } \\
\text { company, } \\
\text { Company's sales } \\
\text { strategies, } \\
\text { Product promotions } \\
\text { and attractive by- } \\
\text { products, } \\
\text { Promotion } \\
\text { campaigns, } \\
\text { Advertising and } \\
\text { product placement } \\
\text { applications }\end{array}$ & $\begin{array}{c}\text { Taste, } \\
\text { Smell, } \\
\text { Color, } \\
\text { Consistency, } \\
\text { Having a } \\
\text { custom made } \\
\text { product (for } \\
\text { Smokers) }\end{array}$ & $\begin{array}{c}\text { Shape and } \\
\text { visual design } \\
\text { on } \\
\text { packaging, } \\
\text { Product } \\
\text { descriptions, } \\
\text { Cover design, } \\
\text { Package size } \\
\text { and } \\
\text { portability }\end{array}$ & $\begin{array}{l}\text { Effects and } \\
\text { comments of } \\
\text { family, } \\
\text { friends, } \\
\text { partner, } \\
\text { social media, } \\
\text { foreign } \\
\text { people, } \\
\text { blogs etc. } \\
\text { when } \\
\text { purchasing } \\
\text { products }\end{array}$ & $\begin{array}{l}\text { Brand and } \\
\text { product trust } \\
\text { (of him/herself), } \\
\text { Reasons to buy } \\
\text { the product again } \\
\text { after using the } \\
\text { toothpaste } \\
\text { The feeling that } \\
\text { you benefit from } \\
\text { the product, } \\
\text { Satisfaction of } \\
\text { your expectations }\end{array}$ & $\begin{array}{c}\text { Natural, } \\
\text { semi-natural } \\
\text { and chemical } \\
\text { content, } \\
\text { Expert } \\
\text { opinions, } \\
\text { Laboratory } \\
\text { testing } \\
\text { techniques, } \\
\text { Laboratory } \\
\text { test results, }\end{array}$ & $\begin{array}{l}\text { Product unit } \\
\text { price, } \\
\text { Retail and } \\
\text { wholesale } \\
\text { price } \\
\text { comparison, } \\
\text { Import or } \\
\text { domestic, } \\
\text { Weight price, } \\
\text { Recycling, } \\
\text { Mobility in } \\
\text { price trends }\end{array}$ \\
\hline
\end{tabular}

\section{RESULTS AND DISCUSSION}

Descriptive statistics of 52 patients was given in Table 4. Results are analyzed statistically and collected from patients. The average age of the patients is $28.93 \pm 9.19$ and the youngest and oldest people of the patients are 19 and 56 years old, respectively.

We put in order to the toothpaste criteria with respect to importance, the criteria for the selection of criterion significance of smokers' decision were taken face to face from patients. From the most important to least important toothpaste selection criteria of the smokers are listed by means of the Fuzzy DEMATEL model (Table 5).

As a result, the most important criterion was found as toothpaste package appearance with a fuzzy weight value of 0.1772 . Price was the second important criterion with a fuzzy weight of 0.1731 , i.e. with a slight difference. Other criteria are the importance of advertising and media effect (0.148), toothpaste content (0.145), influence of people $(0.1277)$, the active ingredients of toothpaste $(0.1234)$ and finally sensation of person $(0.1055)$ respectively.
Table 4. Descriptive statistics of patients. We ask 9 questions to patients and we get this descriptive statistics results.

\begin{tabular}{|c|c|c|}
\hline Variable & Frequency & Percentage \\
\hline \multicolumn{3}{|l|}{ Gender } \\
\hline Male & 34 & $65,38 \%$ \\
\hline Female & 17 & $32,69 \%$ \\
\hline Transsexual & 1 & $1,92 \%$ \\
\hline \multicolumn{3}{|l|}{ Marital status } \\
\hline Single & 36 & $69,23 \%$ \\
\hline Married & 12 & $23,07 \%$ \\
\hline Divorced etc. & 4 & $7,69 \%$ \\
\hline \multicolumn{3}{|l|}{ Education Status } \\
\hline Primary School Unfinished & 1 & $1,92 \%$ \\
\hline Primary School Graduation & 3 & $5,76 \%$ \\
\hline Middle School Graduate & 2 & $3,84 \%$ \\
\hline High School Graduate & 22 & $42,30 \%$ \\
\hline University Graduate & 21 & $40,38 \%$ \\
\hline Others & 2 & $3,84 \%$ \\
\hline \multicolumn{3}{|l|}{ Social Security } \\
\hline None & 4 & $7,69 \%$ \\
\hline Social Security Administration & 28 & $53,84 \%$ \\
\hline $\begin{array}{l}\text { Social Security Organization for Artisans } \\
\text { and the Self-employed }\end{array}$ & 4 & $7,69 \%$ \\
\hline Retirement Fund of Civil Servants & 14 & $26,92 \%$ \\
\hline Others & 2 & $3,84 \%$ \\
\hline \multicolumn{3}{|l|}{ Economic situation } \\
\hline Very Good & 1 & $1,92 \%$ \\
\hline Good & 14 & $26,92 \%$ \\
\hline Medium & 32 & $61,53 \%$ \\
\hline Bad & 3 & $5,76 \%$ \\
\hline Unknown & 2 & $3,84 \%$ \\
\hline \multicolumn{3}{|l|}{ Number of people in the family } \\
\hline One & 6 & $11,53 \%$ \\
\hline Two & 10 & $19,23 \%$ \\
\hline Three & 14 & $26,92 \%$ \\
\hline Four & 15 & $28,84 \%$ \\
\hline Five or Above & 5 & $9,61 \%$ \\
\hline Unknown & 2 & $3,84 \%$ \\
\hline \multicolumn{3}{|l|}{ Number of children } \\
\hline Zero & 35 & $67,30 \%$ \\
\hline One & 12 & $23,07 \%$ \\
\hline Two & 2 & $3,84 \%$ \\
\hline Three or Above & 1 & $1,92 \%$ \\
\hline Unknown & 2 & $3,84 \%$ \\
\hline \multicolumn{3}{|l|}{ The person who makes the most income } \\
\hline The Person Himself & 19 & $9,61 \%$ \\
\hline Relative & 28 & $53,84 \%$ \\
\hline Others & 5 & $36,53 \%$ \\
\hline
\end{tabular}


Table 5. Fuzzy weights of toothpaste selection criteria and the ordering of the criteria's with respect to their importance. The least important criteria is sensation of person and the most important criteria is toothpaste package appearance for the patients.

\begin{tabular}{|c|c|c|c|c|c|c|}
\hline \multicolumn{7}{|c|}{ Fuzzy weights of criteria } \\
\hline \multicolumn{2}{|c|}{0.1234} & 0.1277 & 0.145 & 0.148 & 0.1731 & 0.1772 \\
\hline Ordering of criteria from least important to most important & $\begin{array}{c}\text { Tothpaste } \\
\text { Pensation of } \\
\text { Person }\end{array}$ & $\begin{array}{c}\text { The Active } \\
\text { Ingredients of } \\
\text { Toothpaste }\end{array}$ & $\begin{array}{c}\text { Influence of } \\
\text { People }\end{array}$ & $\begin{array}{c}\text { Toothpaste } \\
\text { Content }\end{array}$ & $\begin{array}{c}\text { Advertising and } \\
\text { Media Effect } \\
\text { Appearance }\end{array}$ \\
\hline
\end{tabular}

\section{CONCLUSION}

According to the analysis; the most important criteria is the appearance of the toothpaste package. According to the information received during the questionnaire, it is foreseen that the patients have such a result due to the importance of the packages information and relation with the customer descriptions. The criteria with the least important is Sensation of Person. The criteria of influence of people is the most effective to other criteria. The criteria of the active ingredients of toothpaste are the most affected by other criteria.

Conflicts of interest

The authors have no conflicts of interest relevant to this article.

E.Alperay Tarım: ORCID ID: 0000-0003-3455-3167 Emel Kuruoğlu Kandemir: ORCID ID: 0000-0003-1881$796 X$

Vildan Mevsim: ORCID ID: 0000-0002-3546-9146

\section{REFERENCES}

1. Akram Z, Vohra F, Bukhari IA, Sheikh SA, Javed F. Clinical and radiographic peri-implant parameters and proinflammatory cytokine levels among cigarette smokers, smokeless tobacco users, and nontobacco users. Clin Implant Dent Relat Res 2018;20:76-81.

2. Preber $\mathrm{H}$, Kant $\mathrm{T}$, Bergström J. Cigarette smoking, oral hygiene and periodontal health in Swedish army conscripts. J Clin Periodontol 1980;7:106-13.

3. Millar WJ, Locker D. Smoking and oral health status. J Can Dent Assoc 2007;73.
4. Vani G, Babu MG, Panchanatham N. Toothpaste Brands-A Study of consumer behavior in Bangalore city. Journal of Economics and Behavioral studies 2010;1:27-39.

5. Karadaş M, Seven N. Vital Tooth Bleaching. Atatürk Üniversitesi Diş Hekimliği Fakültesi Dergisi 2014;9:126-35.

6. Özdemir H, Bayındır F. The Evaluation of Golden Proportion in Persons with Natural Dentitions. Atatürk Üniversitesi Diş Hekimliği Fakültesi Dergisi 2016;26:251-5.

7. WHO. World Health Organization Oral Health Surveys-Basic Methods. World Health Organization 2013.

8. Mortazavi S, Tahririan D, Fathi F. Study of the Selection and Using Method of Toothpaste in 3-5 Years Old Children of Yazd. Journal of ISFAHAN DENTAL SCHOOL 2018;14:45-55.

9. Farooq I, Ali S, Al-Khalifa KS, Alhooshani K. Total and soluble fluoride concentration present in various commercial brands of children toothpastes available in Saudi Arabia-A pilot study. The Saudi dental journal 2018;30:161-5.

10. Singh S. Effectiveness of advertisement on toothpaste product: a case study in Jhajjar district. IJAR 3 2017;1:403-5.

11. Gabus A, Fontela E. World problems, an invitation to further thought within the framework of DEMATEL. Battelle Geneva Research Center, Geneva, Switzerland. 1972;1-8.

12. Lin C-J, Wu W-W. A causal analytical method for group decision-making under fuzzy environment. Expert Systems with Applications 2008;34:20513. 
13. Tzeng $\mathrm{G}-\mathrm{H}$, Chiang $\mathrm{C}-\mathrm{H}$, Li C-W. Evaluating intertwined effects in e-learning programs: A novel hybrid MCDM model based on factor analysis and DEMATEL. Expert systems with Applications 2007;32:1028-44.

14. Opricovic S, Tzeng G-H. Defuzzification within a multicriteria decision model. International Journal of Uncertainty, Fuzziness and Knowledge-Based Systems 2003;11:635-52.

15. $1 \mathrm{Wu}$ W-W, Lee $\mathrm{Y}-\mathrm{T}$. Developing global managers' competencies using the fuzzy DEMATEL method. Expert systems with applications 2007;32:499507.

16. Çinar Y. Kariyer Tercihi Probleminin Yapisal bir Modeli ve Riske Karsi Tutumlar: Olasilikli DEMATEL Yöntemi Temelli Bütünlesik bir Yaklasim/A Structural Model of Career Preference Problem and Attitudes Towards Risk: A Hybrid Approach based on Stochastic DEMATEL Method. Sosyoekonomi 2013;1:157.

\section{Yazışma Adresi}

Ergün Alperay Tarım İzmir Yüksek Teknoloji Enstitüsü, Moleküler Biyoloji ve Genetik Binası, Zemin Kat, Oda No: K009, Urla/İzmir GSM: +905516518261

e-mail: alperaytarim@gmail.com erguntarim@iyte.edu.tr alperay.tarim@ogr.deu.edu.tr 